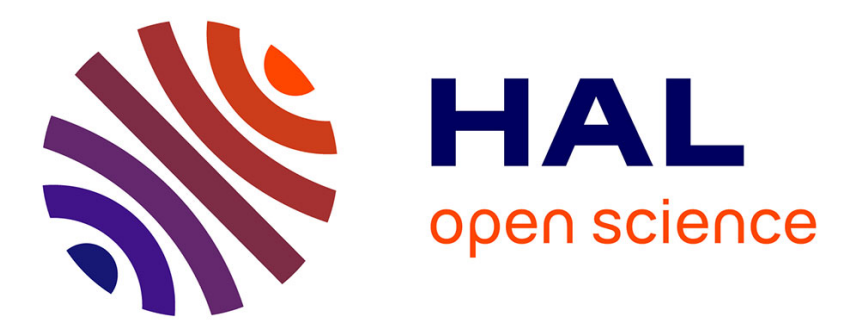

\title{
Mercury in the ecosystem of Admiralty Bay, King George Island, Antarctica: Occurrence and trophic distribution
}

Caio C Cipro, Rosalinda C Montone, Paco Bustamante

\section{To cite this version:}

Caio C Cipro, Rosalinda C Montone, Paco Bustamante. Mercury in the ecosystem of Admiralty Bay, King George Island, Antarctica: Occurrence and trophic distribution. Marine Pollution Bulletin, 2017, 114, pp.564 - 570. 10.1016/j.marpolbul.2016.09.024 . hal-01431477

\author{
HAL Id: hal-01431477 \\ https://hal.science/hal-01431477
}

Submitted on 10 Jan 2017

HAL is a multi-disciplinary open access archive for the deposit and dissemination of scientific research documents, whether they are published or not. The documents may come from teaching and research institutions in France or abroad, or from public or private research centers.
L'archive ouverte pluridisciplinaire HAL, est destinée au dépôt et à la diffusion de documents scientifiques de niveau recherche, publiés ou non, émanant des établissements d'enseignement et de recherche français ou étrangers, des laboratoires publics ou privés. 


\section{Mercury in the ecosystem of Admiralty Bay, King George Island, Antarctica: Occurrence and trophic distribution}

Caio V. Z. Cipro ${ }^{1,2^{*}}$, Rosalinda C. Montone ${ }^{1}$, Paco Bustamante ${ }^{2}$

${ }^{1}$ Laboratório de Química Orgânica Marinha, Instituto Oceanográfico, Universidade de São Paulo, 05508-120 São Paulo, SP, Brazil

${ }^{2}$ Littoral Environnement et Sociétés (LIENSs), UMR 7266, CNRS-Université de La Rochelle, 2 rue Olympe de Gouges 17042 La Rochelle Cedex 01, France

* Corresponding autor: Laboratório de Química Orgânica Marinha Instituto Oceanográfico Universidade de São Paulo 05508-120 São Paulo, SP

Brazil.

E-mail address: caiovzc@usp.br 


\begin{abstract}
Mercury $(\mathrm{Hg})$ can reach the environment through natural and human-related sources, threatening ecosystems all over the planet due to its well-known deleterious effects. Therefore, Antarctic trophic webs, despite being relatively isolated, are not exempt of its influence. To evaluate $\mathrm{Hg}$ concentrations in an Antarctic ecosystem, different tissues from 2 species of invertebrates, 2 of fish, 8 of birds, 4 of pinnipeds and at least 5 of vegetation were investigated $(n=176)$. For animals, values ranged from 0.018 to $48.7 \mu \mathrm{g} \mathrm{g}^{-1} \mathrm{dw}$ (whole Antarctic krill and Antarctic Fur Seal liver). They were generally correlated to trophic position (assessed by $\delta^{15} \mathrm{~N}$ and $\delta^{13} \mathrm{C}$ ) but also to cephalopods and myctophids consumption. For vegetation, values ranged from 0.014 to $0.227 \mu \mathrm{g} \mathrm{g}^{-1} \mathrm{dw}$ (Colobanthus quitensis and an unidentified lichen), with lichens presenting significantly higher values than mosses, likely due to year-round exposure and absorption of animal derived organic matter, as hypothesized by literature.
\end{abstract}

Keywords: mercury; Antarctica; stable isotopes; food web 
Mercury ( $\mathrm{Hg}$ ), besides its natural sources, can reach the environment through humanrelated activities, such as mining and the burning of fossil fuels (Fitzgerald et al., 1998, 2007; Selin, 2009). Indeed, non-natural sources play a major role in $\mathrm{Hg}$ deposition, estimated to occur in a current rate three to five times higher than its pre-industrial times (Selin, 2009).

In the open ocean the main $\mathrm{Hg}$ source is atmospheric deposition of inorganic $\mathrm{Hg}$ (II) by both wet and dry processes (e.g. Fitzgerald et al., 2007). Over $80 \%$ of the Hg deposited in marine ecosystems is reemitted to the atmosphere $(\operatorname{as~} \operatorname{Hg}(0)$ predominantly, but some as $(\mathrm{CH} 3)_{2} \mathrm{Hg}$ ), increasing the residence time of $\mathrm{Hg}$ cycling through the reservoirs of the surface biosphere (Driscoll et al., 2013). Once in the water column, inorganic Hg can be methylated by anaerobic microorganisms, such as sulphate-reducing and iron-reducing bacteria (e.g. HsuKim et al., 2013). The produced Me-Hg (mono-methyl-Hg) is then easily assimilated by the biota and biomagnifies up the food web (e.g. Morel et al., 1998). Because microorganisms activity is importantly influenced by temperature, springtime conversion of $\mathrm{Hg}$ into $\mathrm{Me}-\mathrm{Hg}$ may provide an important environmental pathway for its introduction into the biosphere in a time of the year when biota are preparing for peak summertime activity (Schroeder et al., 1998).

In the Southern Hemisphere, high concentrations of atmospheric $\mathrm{Hg}$ have been observed close to the Antarctic continent when compared to lower latitudes (Soerensen et al., 2010). Antarctica, in spite of being the most isolated continent on Earth, is far from exempt of the input of several sorts of contaminants, including Persistent Organic Pollutants such as PCBs or organochlorine pesticides, as reported in literature (e.g. Bargagli et al., 2007; Corsolini, 2009). Antarctica is thus contaminated by anthropogenic $\mathrm{Hg}$ which can affect the fitness of organisms and have consequences at the population level as shown on polar skuas (Goutte et al., 2014).

Investigating contaminants such as $\mathrm{Hg}$ in trophic webs can be greatly improved by using stable isotopes of carbon and nitrogen as an ecological tool to shed light, respectively, the carbon sources exploited by consumers and their trophic position (Lesage et al., 2002). Previous studies on Arctic ecosystems have already shown that $\mathrm{Hg}$ analyses coupled to $\delta^{15} \mathrm{~N}$ (e.g. Atwell et al., 1998) or both $\delta^{13} \mathrm{C}$ and $\delta^{15} \mathrm{~N}$ (e.g. Aubail et al., 2011) allows a better understanding of $\mathrm{Hg}$ biomagnification pathways and moreover, the influence of feeding ecology factors such as change in feeding sites, gender or age class trophic segregation, i.e., trophic position as a whole.

Since the late 70s, organic contaminants have received interest in King George Island (Lukowski, 1978) but with a relative lack of data for stable isotopes, with only a small quantity of studies taking SIA into account (e.g. Corbisier et al., 2004 and Majer et al., 2014 
for benthic invertebrates; Cipro et al., 2011 for vegetation), particularly for upper vertebrates (e.g. Cipro et al., 2012). Also, a lack of Hg data (e.g. dos Santos et al., 2006) is obvious for the organisms from this area. In this context, this study is the first, to the best of our knowledge, coupling $\mathrm{Hg}$ and isotopic data for organisms from King George Island.

Taking all of that into account, the study aims at assessing $\mathrm{Hg}$ concentrations in the light of SI ratios; at raising hypotheses on how these results are influenced by one another and also by ecological factors such as diet, distribution, exposure pathways and so on; and finally, at comparing the results with those from literature, investigating the factors that might play important roles in these eventual differences.

Sample collection took place in King George Island $\left(62^{\circ} 05^{\prime} \mathrm{S}, 058^{\circ} 23^{\prime} \mathrm{W}\right)$, the largest one of the South Shetland Islands, separated from the northern portion of the Antarctic Peninsula by the Bransfield Strait. The number of samples of each species, tissue and analysis is given in Table 1. All samples were kept in previously combusted (at least $420{ }^{\circ} \mathrm{C}$ for at least $4 \mathrm{~h}$ ) containers, frozen upon arrival $\left(-20^{\circ} \mathrm{C}\right)$ at the Brazilian Antarctic Station and kept frozen until freeze-drying in the LabQOM(University of São Paulo, Brazil).Hg and stable isotope analyses (SIA) analyses were performed at the University of La Rochelle (France). Briefly, bird eggs and tissues, fish and invertebrate samples were collected according to Cipro et al. (2010, 2013). Limpets (Antarctic limpet, Nacella concinna) were manually collected (2004-05 summer) in the intertidal zone. Fish (marbled rockcod, Notothenia rossii and black rockcod $N$. coriiceps) were collected (2006-07 summer) by mid-water nets or by line and hook. Only unhatched bird eggs (skua, Catharacta sp., identified only until the genus level; kelp gull, Larus dominicanus; and Antarctic tern, Sterna vittata) were collected (2004-05 and 2005-06 summers) so as not to interfere with breeding success. Bird livers (cape petrel, Daption capense and giant petrel, Macronectes giganteus in addition to the previous species) were collected (from 2004-05 up to 2007-08 summers) only from already dead animals with no evident signs of disease, decomposition or emaciation. No further attempt to determine the cause of death was performed. Pinnipeds samples were collected according to Cipro et al. (2012), which already contains the SIA data: samples of the Weddel seal, Leptonychotes weddellii; Antarctic fur seal, Arctocephalus gazella; crabeater seal, Lobodon carcinophagus; and southern elephant seal, Mirounga leonina, were collected during the austral summers of 2004/05 and 2005/06, in a fully opportunistic manner, i.e., only from animals found already dead, with no signs of degradation. Finally, vegetation samples were collected according to Cipro et al. (2011), which contains also the SIA data: the angiosperm Colobanthus quitensis, the mosses Brachythecium sp., Syntrichia princeps and Sanionia uncinata and the lichens 
Usnea aurantiaco-atra and Usnea antarctica were collected from early December 2004 to early January 2005.

Prior to stable isotope and $\mathrm{Hg}$ analyses, samples were lyophilized and ground to obtain a fine powder and stored in plastic vials.

Mercury analyses were carried out with an Automatic Mercury Analyser spectrophotometer, ALTEC AMA 254, which does not require an acid digestion of the samples. Aliquots ranging from 10 to $50 \mathrm{mg}$ of freeze-dried sample (with no delipidation whatsoever) were directly analysed after being inserted in the oven of the apparatus. After drying, the samples were heated under an oxygen atmosphere for $3 \mathrm{~min}$, and the $\mathrm{Hg}$ liberated and subsequently amalgamated on an Au-net. The net was then heated to liberate the collected $\mathrm{Hg}$, which was measured by Atomic Absorption Spectrometry (AAS). Accuracy and reproducibility of the method were tested using dogfish liver (DOLT-2) and muscle (DORM2) and lobster hepatopancreas (TORT-2) (National Research Council, Canada) reference standards. Standard and blanks were analysed along with each set of samples, and recoveries of the certified values and recoveries of the metals ranged from 93 to $109 \%$. Measurements were also validated by IAEA inter-calibration exercises (Coquery et al., 2001). Concentrations are expressed in dry weight in order to compensate eventual moisture loss during freezing and to facilitate comparison between tissues and with other studies. Blanks were analysed at the beginning of each set of samples, and the detection limit of the method was $0.005 \mu \mathrm{g} \mathrm{g}^{-1}$ dry mass. Lipid content values and obtaining methods have been previously published (Cipro et al., 2011, 2012, 2013).

For SIA, one aliquot of approx. 100mg of sample was placed in a test tube with $4 \mathrm{~mL}$ of cyclohexane to remove lipids according to Chouvelon et al. (2012a) as lipids are depleted in ${ }^{13} \mathrm{C}$. The mixture was shaken for an hour, then centrifuged for separation and the liquid discarded. This procedure was repeated as many times as needed until the liquid phase comes out clear. The delipidated pellet was then dried at $50{ }^{\circ} \mathrm{C}$ for $48 \mathrm{~h}$. Aliquots were analysed using a Thermo Scientific Delta V Advantage, ConFlo IV interface (NoBlank and SmartEA) and Thermo Scientific Flash EA1112 Elemental Analyser. Each injection corresponded to $0.4 \pm 0.1 \mathrm{mg}$ for animal sample or $1.0 \pm 0.1 \mathrm{mg}$ for vegetation samples, encapsulated in tin cups, and there were no replicates unless $\mathrm{C} / \mathrm{N}$ ratio were above than 4 . In this case, delipidation would be repeated until this condition was met. Pee Dee Belemnite and atmospheric nitrogen were used as standards for calculation of $\delta^{13} \mathrm{C}$ and $\delta^{15} \mathrm{~N}$, respectively. Based on replicate measurements of internal laboratory standards, experimental precision is of $\pm 0.15 \%$ and $\pm 0.20 \%$ for $\delta^{13} \mathrm{C}$ and $\delta^{15} \mathrm{~N}$, respectively. 
Statistics were performed using Microsoft Excel and Statsoft Statistica 12. Before analyses, data were checked for normality of distribution and homogeneity of variances using Shapiro-Wilk and Brown-Forsythe tests, respectively. Parametrical (Pearson's productmoment correlation, Tukey's HSD/ANOVA) and non-parametrical tests (Spearman's rank correlation, Kruskal-Wallis/ANOVA) followed accordingly. Statistically significant results were set at $\alpha=0.05$.

Finally, normal distribution and log-link function generalized linear models (GLM) were built as follows: $\mathrm{Hg}$ concentrations as the dependent variable, species and tissue as categorical factors and $\delta^{13} \mathrm{C}$ and $\delta^{15} \mathrm{~N}$ values as continuous predictors. Biologically relevant models were constructed incorporating the different variables and their interactions.

Continuous variables $\left(\delta^{13} \mathrm{C}\right.$ and $\left.\delta^{15} \mathrm{~N}\right)$ were not significantly correlated in the whole dataset and could be included in the same models. Model selection was based on Akaïke's Information Criteria adjusted for small sample sizes (AICc). The model with the lowest AICc value was considered to be the most accurate. Models with AICc values differing by less than 2 have a similar level of support in the data, and the model including the least number of parameters can be regarded as the most accurate, according to the principle of parsimony (Burnham and Anderson, 2002). Overall model support was assessed using Akaike weights (wi), following (Johnson and Omland, 2004). Residual ( $\mathrm{R}^{2}$ adj) analyses should be restricted to description and not be used in model selection (Burnhamand Anderson, 2002). Only models with AICc values differing by less than 10 are presented.

The results for $\mathrm{Hg}$ and SIA are presented in Table 1. In regard to intraspecific data for animals, the Antarctic krill, Euphausia superba, presented the lowest Hg concentration of the whole animal dataset $\left(0.018 \pm 0.005 \mu \mathrm{g} \mathrm{g}^{-1}\right)$, which comes in agreement with its low trophic level. Reported $\mathrm{Hg}$ concentrations for this species from different areas were in the same order of magnitude ranging from 0.016 to $0.041 \mu \mathrm{g} \mathrm{g}^{-1}$ along the Antarctic Peninsula (Locarnini and Presley, 1995), averaged $0.033 \pm 0.013 \mu \mathrm{g} \mathrm{g}^{-1}$ (after dry weight conversion) in several locations ranging from 63 to $68^{\circ} \mathrm{S}$ and from 126 to $147^{\circ} \mathrm{W}$ and also from 107 to $157^{\circ} \mathrm{E}$ (Yamamoto et al., 1987) and, with values averaging $0.035 \mu \mathrm{g} \mathrm{g}^{-1}$ in the same area as in the present study (dos Santos et al., 2006). These authors also bring data for Nacella concinna, averaging $0.026 \mu \mathrm{g} \mathrm{g}^{-1}$, also consistent with our findings.

The SIA data for the invertebrates show two clearly distinct $\delta^{13} \mathrm{C}$ signatures: a depleted pelagic/oceanic for E. superba and a much more enriched for the benthic/coastal $N$. concinna. These values are similar to the ones reported by a comprehensive study in the same region (Corbisier et al., 2004) and are key to understand the mixing of benthic/pelagic organic matter sources throughout the local food web. This is due to the fact that, besides the feeble trophic 
enrichment of $\delta^{13} \mathrm{C}$ (DeNiro and Epstein, 1978) and also possible migration (e.g. Cherel et al., 2006), the consumption of both sources will result in a proportionally intermediate signature (e.g. Carravieri et al., 2013), and therefore, clarify feeding ecology for a given species. Even though both these invertebrates are primary consumers, there is an important difference in their $\delta^{15} \mathrm{~N}$ (i.e., $2.7 \%$, Table 1).However, the signature of the primary producers they consume presents a similar difference: $0.5 \%$ for phytoplankton and $4 \%$ for microphytobenthos in this region (Dunton, 2001), i.e., 3.5\%o. Thus, the difference found is indeed a matter of baseline nitrogen signature of the organisms on which they prey and not of trophic level itself (Chouvelon et al., 2012b). According to the significant negative correlation between $\mathrm{Hg}$ and $\delta^{13} \mathrm{C}(\rho=-0.828$, paired $\mathrm{n}=6)$ in Nacella concinna, it seems that some $\delta^{13} \mathrm{C}$ depleted food items might represent a $\mathrm{Hg}$ source for this mollusc, since it feeds mainly on the relatively $\delta^{13} \mathrm{C}$-enriched microphytobenthos (Corbisier et al., 2004), but the diet of this species also comprises microbial films (grazing on the microepiflora), calcareous rhodophytes, seaweed, bryozoans and sessile spirorbid polychaetes (Suda et al., 2015). Moreover, a local abiotic compartment may act like an indirect source, similarly as described by Mão de Ferro et al. (2014): limpet samples were collected in the intertidal zone, in most cases next to glaciers, therefore subject to snow melting water, glaciers seasonal melting water (which percolates soil and bedrock before reaching the shore), marine spray, which might all function as $\mathrm{Hg}$ sources to the limpets themselves via respiration or to the organisms they feed on. These factors might influence $\delta^{15} \mathrm{~N}$ as well, but apparently not in a significant way.

As for the Notothenia spp., muscle $\mathrm{Hg}$ concentrations for $N$. rossii from Kerguelen waters (averaging $0.255 \mu \mathrm{g} \mathrm{g}^{-1} \mathrm{dw}$ ) were three times higher than the present results (Bustamante et al., 2003). N. coriiceps from Laurie Island (South Orkney Islands) presented $\mathrm{Hg}$ concentration of $0.200 \mu \mathrm{g} \mathrm{g}^{-1} \mathrm{dw}$ (converted from the fresh wt assuming a $75 \%$ water content) (Moreno et al., 1997). Surprisingly, this value is closer to Bustamante et al. (2003) than to our findings whereas Laurie Island are situated south from the Polar Front and Kerguelen Islands, north. Indeed, predators north of the Polar Front show higher $\mathrm{Hg}$ concentrations than those from the southern area. For example, wandering albatrosses foraging South the Polar front are less exposed to $\mathrm{Hg}$ than those feeding north (Bustamante et al., 2016; Carravieri et al., 2014b). Lower values compared to our results were also reported for Notothenia spp. (with data for whole fish averaging $0.016 \mu \mathrm{g} \mathrm{g}^{-1}$; dos Santos et al., 2006), but the analysed individuals are assumed to be juveniles. In adult $N$. coriiceps from Adélie land, muscle $\mathrm{Hg}$ concentrations were one order of magnitude higher, i.e., $0.221 \pm 0.085 \mu \mathrm{g} \mathrm{g}^{-1}$ $\mathrm{dw}$ (Goutte et al., 2015). The $\delta^{13} \mathrm{C}$ signature found in these fish is intermediate in regard to $E$. 
superba and $N$. concinna which is likely due to the consumption of both oceanic/pelagic and coastal/benthic prey. Moreover, the significant positive correlation between $\delta^{13} \mathrm{C}$ and $\delta^{15} \mathrm{~N}$ ( $\rho=0.662)$ in $N$. rossii confirms that this fish displays ontogenic changes with growth: as the fish grows, higher trophic level prey is increasingly preferred, specially small fish (Burchett, 1983).

Data for Catharacta sp. eggs appears as the most contaminated for this tissue. This might be due to the high trophic level of this species, as shown by elevated $\delta^{15} \mathrm{~N}$. Skuas are opportunistic feeders (Reinhardt et al., 2000) and prey on other birds: eggs, chicks or the adults themselves. In locations where skuas have developed a specialisation of their diet such as in Mayes Island in the Kerguelen archipelago, chicks are fed mainly with blue petrels (Mougeot et al., 1998) and they consequently present higher feather $\mathrm{Hg}$ levels than adults as a reflect of age class feeding habits' differences (Carravieri et al., 2014a). Indeed, the parents feed on low trophic level prey in Antarctic waters (Cherel et al., 2002, 2006), with a large proportion of mesopelagic fish (Cherel et al., 2002; Connan et al., 2008). In turn, breeding skuas in King George Island feed mainly on penguins and their eggs, and fish, varying somewhat between these two prey groups for the two occurring species in this location (Peter et al., 1990). Nevertheless, considering feather data (Carravieri et al., 2014b), as well as diet (Bocher et al., 2003), it is reasonable to assume that this diet would lead to high $\mathrm{Hg}$ exposure to skua from the present work. In eggs, the present values $\left(2.520 \pm 1.709 \mu \mathrm{g} \mathrm{g}^{-1} \mathrm{dw}\right)$ are higher when compared to the $1.61 \pm 1.22 \mu \mathrm{g} \mathrm{g}^{-1} \mathrm{dw}$ for $C$. maccormicki eggs from a previous study conducted in Terra Nova Bay (Bargagli et al., 1998a). Even though in seabirds showing gender differences in their foraging strategies such as wandering albatrosses whose females had higher $\mathrm{Hg}$ concentrations than males despite the excretion through the eggs because they forage in more contaminated waters (north) than males (south) (Carravieri et al., 2014a), in regard to skuas there seems to be no gender segregation in both $\mathrm{Hg}$ concentration and SIA, not even during the breeding season (Bearhop et al., 2000a).

SIA data puts skuas in roughly the same ecological niche as previous literature (Bearhop et al., 2000a, 2000b), particularly when liver is compared to blood, since both these tissues have short and similar turnover rates (Hobson and Clark, 1992). Unpublished data (Cipro et al., personal data) confirms these previous statements, also presenting sub-Antarctic species (from Kerguelen) with higher $\mathrm{Hg}$ concentrations than Antarctic ones (from Adélie Land) occupying similar ecological niches, the Cape petrel Daption capense presented remarkably high $\mathrm{Hg}$ concentrations despite its $\delta^{15} \mathrm{~N}$ closer to penguins which showed much lower Hg concentrations. Such high concentrations might be due to two factors. The first one is that its diet is, in a general way, almost entirely composed by oceanic/pelagic prey (Coria et 
al., 1997) whereas pygoscelids penguins might, in a lesser way, consume some coastal/benthic prey (especially Gentoo penguins, P. papua). Pygoscelids also show a reproductive temporal shift, mostly due to their respective distributions, and not necessarily to food availability. These penguins breed in different periods of the austral summer in this area, with Adélies early breeding, followed by Gentoos and then Chinstraps (Trivelpiece et al., 1987). The second one is that most of the Cape petrel diet in the region (Casaux et al., 1998; Coria et al., 1997) is composed by Myctophidae fish, which have higher $\mathrm{Hg}$ concentrations compared to epipelagic ones (e.g., Chouvelon et al., 2012a; Monteiro et al., 1996) and species that prey on these resources are therefore more prone to accumulate $\mathrm{Hg}$ (Blévin et al., 2013; Carravieri et al., 2014b; Cipro et al., 2014).

The giant Petrel Macronectes giganteus showed much higher $\mathrm{Hg}$ concentrations in the present study than the reports from the literature. In giant petrels from Bird Island, South Georgia, $\mathrm{Hg}$ concentrations in the liver were averaging 2.16 (males) and 4.95 (females) $\mu \mathrm{g} \mathrm{g}^{-1}$ dw (González-Solís et al., 2002) i.e., from 5 to 10 times lower than our findings. Birds sampled in the South Shetland Islands and the Antarctic Peninsula had also Hg concentrations one order of magnitude lower, averaging $1.37 \mu \mathrm{g} \mathrm{g}^{-1} \mathrm{dw}$ (Szefer et al., 1993). This marked difference could be due to our small sampling number or to some local effect, since our samples present similar SIA levels to those from Bird Island, South Georgia, the closest site that could be found in the literature for comparison (Forero et al., 2005).

$\mathrm{Hg}$ concentrations in the eggs of Gentoo penguins $P$. papua and Adélie penguins $P$. adeliae were similar to that reported in the literature (Moreno et al., 1997, after dry weight conversion assuming $70 \%$ water content), i.e., $\sim 0.13 \mu \mathrm{g} \mathrm{g}^{-1} \mathrm{dw}$. This same work also presents data for $P$. adeliae liver, $\sim 1.5 \mu \mathrm{g} \mathrm{g}^{-1} \mathrm{dw}$, also in the same range with our findings. As for liver, literature shows more contaminated liver samples for two pygoscelids in Szefer et al. (1993), averaging 2.01 (P. adeliae) and $34.7 \mu \mathrm{g} \mathrm{g}^{-1} \mathrm{dw}$ (P. papua). However, Smichowski et al. (2006) presents data six times lower for P. adeliae chicks' liver collected also in King George Island, which provides evidence of $\mathrm{Hg}$ bioaccumulation in this species. Significant correlations for birds are broken down in Fig. 1. Only paired analyses are shown, therefore the number of samples may vary in regard to the total.

Since pygoscelids fast during the egg formation period (Astheimer and Grau, 1985; Polito et al., 2011), the influence on egg results of the trophic level of prey during breeding season is not to be considered. The significant negative correlation between $\mathrm{Hg}$ and $\delta^{13} \mathrm{C}(\rho=$ -0.627 ) in $P$. antarctica eggs could be related to the fact that fasting breeding adult penguins present a decrease in $\delta^{13} \mathrm{C}$ plasma signature during fasting (Cherel et al., 2005), whereas $\mathrm{Hg}$ levels might increase simply due to the opposite of the growth dilution effect on egg laying 
females and consequent transfer (e.g. Agusa et al., 2005). A significant negative correlation was found between $\mathrm{Hg}$ and $\delta^{15} \mathrm{~N}(\rho=-0.900)$ in P. papua egg could be related to different proportions of fish and squid in the diet prior to breeding (Polito et al., 2011). Since the Gentoo penguin presents considerable plasticity in its diet when compared to the other two less flexible pygoscelids (Miller et al., 2009), consuming prey from coastal/oceanic and benthic/pelagic origins could result in different $\delta^{15} \mathrm{~N}$ baselines and therefore misleading conclusions (see Chouvelon et al., 2012b). This is a similar issue as previously discussed for krill and limpets.

The significant positive correlation between $\delta^{13} \mathrm{C}$ and $\delta^{15} \mathrm{~N}(\rho=0.562)$ in $P$. antarctica liver is due to the concomitant enrichment of these elements even though it occurs in a much lesser degree for ${ }^{13} \mathrm{C}$ (DeNiro and Epstein, 1978). Finally, a significant positive correlation was found between $\mathrm{Hg}$ and $\delta^{15} \mathrm{~N}(\rho=0.615)$ in $P$. papua liver likely due to the consumption of higher trophic level prey for adults all year round.

$\mathrm{Hg}$ concentrations for the eggs of the kelp gull Larus dominicanus fall within the same order of magnitude than the value (i.e., $0.46 \mu \mathrm{g} \mathrm{g}^{-1}$ ) reported by Moreno et al. (1997) but data for deeper comparison are dramatically lacking for this species. However, Hg concentrations in the liver was the second highest value for seabirds, which is likely due to the influence of high consumption rates of $N$. concinna during the austral summer (Favero et al., 1997). The influence of this benthic prey can also be seen in the highly enriched $\delta^{13} \mathrm{C}$ signature in kelp gull liver and moreover, in the resulting PCB congener profiles in L. dominicanus, already highlighted in a previous study (Cipro et al., 2013).

The Antarctic tern Sterna vittata is, in this study, a sui generis case, firstly because only one sample was available and secondly because its SIA results would suggest a coastal/benthic diet whereas the literature (Casaux et al., 2008) reports it as a pelagic predator. More samples are needed to explore this contradictory observation.

Pinnipeds will be further discussed as a group due to the very small and disperse sampling.

For animals interspecific data, two statistically (Tukey HSD tests) different intrahomogenous groups for $\mathrm{Hg}$ levels: one group with the giant petrel Macronectes giganteus liver and one group with all the other samples. This relative homogeneity around the Antarctic Peninsula had previously been reported by Brasso et al. (2012).

Particularly for pinnipeds, the data for A. gazella and M. leonina liver are clearly distinguished from the others. A previous analysis of the SIA data (Cipro et al., 2012) for $A$. gazella had already shown a clear shift in foraging area (closer to the shore) and towards higher trophic level, probably due to the increase of fish consumption. All of this corroborates 
this much increased $\mathrm{Hg}$ value, adding up to the fact that they stand on a higher trophic level and are more prone to biomagnification. Interpretation for $M$. leonina is yet more complicated since sex-specific foraging strategies are reported (Cherel et al., 2008; Lewis et al., 2006): in a general way females' diets vary less than the ones of males. Females forage mostly on low trophic level prey from deep waters, such as cephalopods or myctophid fish (according to the location), whereas, males appear to be specialist foragers, divided among several different strategies, which might also include pelagic invertebrates, benthic fish and adult pelagic fish. Such a difference can be seen as a strategy to avoid intra and interspecies competition, especially during the breeding season (Cherel et al., 2008; Lewis et al., 2006). Comparison with Szefer et al. (1993) shows that Lobodon carcinophagus muscle $\mathrm{Hg}$ concentrations are one order of magnitude lower and the ones of Leptonychotes weddellii kidney were two orders of magnitude lower. Since no sex, age or biometrics data could be taken, the interpretation cannot go any further.

Concerning intraspecific data for vegetation, $\mathrm{Hg}$ values for several moss species from Edmonson Point, Antarctica ranged from 0.05 to $0.15 \mu \mathrm{g} \mathrm{g}^{-1} \mathrm{dw}$ (Bargagli et al., 1998b), which comes in reasonable agreement with the data from the present study. Another work, in the same area as the present one (dos Santos et al., 2006) presents values for mosses of 0.023 (Bryum spp.) and 0.040 (Polytrichum spp.) $\mu \mathrm{g} \mathrm{g}^{-1}$, which are roughly 1.5 to 5 times lower than the ones hereby reported. Also, $\mathrm{Hg}$ concentrations of $0.036 \mu \mathrm{g} \mathrm{g} \mathrm{g}^{-1}$ for lichens (Usnea spp.) are 4 times lower than the ones from the present work, in average. Significant positive correlation between $\mathrm{Hg}$ and $\delta^{13} \mathrm{C}(\rho=0.828)$ in Sanionia uncinata could be related to a lesser marine influence, as further discussed.

For vegetation, Tukey HSD tests separated the less Hg contaminated mosses Syntrichia princeps and Sanionia uncinata from the more $\mathrm{Hg}$ contaminated lichens Usnea spp. in two statistically different intra-homogenous groups. This finding comes in agreement with physiologic differences, mainly water dependence. An analogous separation between lichens and mosses is noticed in Cipro et al. (2011) for POPs. And since moister habitats and marine influence are related to lower $\delta^{13} \mathrm{C}$ and higher $\delta^{15} \mathrm{~N}$ (Lee et al., 2009), it would be reasonable to assume that dry deposition phenomena are more significant as $\mathrm{Hg}$ source in this case. However, the clear influence of secondary sources in recent literature (Choy et al., 2010; Cipro et al., 2011; Roosens et al., 2007) might overcome that conclusion. Therefore our results differ largely from the ones by dos Santos et al. (2006) not only in an intraspecific way, but also, and mainly, in the clear difference between lichens and mosses Hg levels.

In order to understand the Influence of species, tissue, $\delta^{13} \mathrm{C}$ and $\delta^{15} \mathrm{~N}$ on how these variables affect the resulting $\mathrm{Hg}$ concentrations in this large array of samples, normal 
distribution and log-link function generalized linear models (GLM) were built as previously described. The whole dataset was split in animals and vegetation subsets and model results are shown in Table 2. Taking the results into account, the best model to explain $\mathrm{Hg}$ levels in the fauna is composed by both $\delta^{15} \mathrm{~N}$ and tissue, followed by $\delta^{15} \mathrm{~N}$, species and tissue. Examples of the importance of such variables in the accumulation of trace elements are found throughout the scientific literature: $\delta^{15} \mathrm{~N}$ (e.g. Anderson et al., 2010), tissue (e.g. Bustamante et al., 2003) and species (e.g. Borgå et al., 2006) as well as for both $\delta^{15} \mathrm{~N}$ and tissue (e.g. Campbell et al., 2005), as in our findings.

The models for vegetation, in turn, are composed by $\delta^{13} \mathrm{C}$ and species followed by $\delta^{13} \mathrm{C}$, $\delta^{15} \mathrm{~N}$ and species. Firstly, it is, in a broad sense, the repetition of Tukey HSD tests previously performed, since mosses and lichens were placed in two statistically different groups and moreover, a clear separation in $\delta^{13} \mathrm{C}$ for lichens and mosses, with no overlapping whatsoever, can be noticed in Cipro et al. (2011). The influence of $\delta^{15} \mathrm{~N}$ in $\mathrm{Hg}$ concentrations, which in vegetation cannot be linked to trophic level is, firstly, linked to $\delta^{13} \mathrm{C}$ (Cipro et al., 2011; Park et al., 2009) and also thought to be linked to the exposure to secondary contaminant sources, particularly the degradation of animal derived organic matter (Cipro et al., 2011).

\section{Acknowledgements}

The authors acknowledge the financing organisations in the University of La Rochelle: CPER (Contrat de Plan État-Région) and FASEP (Fonds d'étude et d'aide au secteur privé). C.V.Z. Cipro received scholarships from CAPES (Coordination for the Improvement of Higher Education Personnel via the Science without Borders programme, Brazil, grant number 11490/13-6) during the course of this work. The present work is a result of the projects "Environmental Management of Admiralty Bay, King George Island, Antarctica: persistent organic pollutants and sewage" (CNPq No. 55.0348/2002-6), and "Modeling the bioaccumulation of organic pollutants throughout an Antarctic food web" (CNPq 550018/2007-7) and also contributes to the Brazilian National Science and Technology Institute on Antarctic Environmental Research (INCTAPA). Financial support was obtained from the Brazilian Antarctic Program (PROANTAR), Ministry of the Environment (MMA) and Conselho Nacional de Desenvolvimento Cientifico e Tecnológico (CNPq). Antarctic logistics was provided by Secretaria da Comissão Interministerial para os Recursos do Mar. (SECIRM). C. Churlaud and M. Brault-Favrou from the "Plateforme Analyses Elémentaires" of LIENSs are thanked for their assistance during $\mathrm{Hg}$ analyses. G. Guillou and B. Lebreton from the "Plateforme Analyses Isotopiques" of LIENSs are thanked for their assistance during SIA analyses. Finally, authors wish many thanks to everyone involved in the fieldwork.

\section{References}

Agusa, T., Matsumoto, T., Ikemoto, T., Anan, Y., Kubota, R., Yasunaga, G., Kunito, T., Tanabe, S., Ogi, H., Shibata, Y., 2005. Body distribution of trace elements in black-tailed gulls from Rishiri Island, Japan: age-dependent accumulation and transfer to feather and eggs. Environ. Toxicol. Chem. 24, 2107-2120. 
Anderson, O.R.J., Phillips, R.A., Shore, R.F., McGill, R.A.R., McDonald, R.A., Bearhop, S., 2010. Element patterns in albatrosses and petrels: influence of trophic position, foraging range, and prey type. Environ. Pollut. 158, 98-107.

Astheimer, L.B., Grau, C., 1985. The timing and energetic consequences of egg formation in the Adélie penguin. Condor 87, 256-268.

Atwell, L., Hobson, K.,Welch, H., 1998. Biomagnification and bioaccumulation of mercury in an arctic marine food web: insights from stable nitrogen isotope analysis. Can. J. Fish. Aquat. Sci. 1121, 1114-1121.

Aubail, A., Teilmann, J., Dietz, R., Rigét, F., Harkonen, T., Karlsson, O., Rosing-Asvid, A., Caurant, F., 2011. Investigation of mercury concentrations in fur of phocid seals using stable isotopes as tracers of trophic levels and geographical regions. Polar Biol. 34, 14111420.

Bargagli, R., Monaci, F., Sanchez-Hernandez, J.C., Cateni, D., 1998a. Biomagnification of mercury in an Antarctic marine coastal food web. Mar. Ecol. Prog. Ser. 169, 65-76.

Bargagli, R., Sanchez-Hernandez, J., Martella, L., Monaci, F., 1998b. Mercury, cadmium and lead accumulation in Antarctic mosses growing along nutrient and moisture gradients. Polar Biol. 19, 316-322.

Bargagli, R., Monaci, F., Bucci, C., 2007. Environmental biogeochemistry of mercury in Antarctic ecosystems. Soil Biol. Biochem. 39, 352-360.

Bearhop, S., Phillips, R.A., Thompson, D.R., Waldron, S., Furness, R.W., 2000a. Variability in mercury concentrations of great skuas Catharacta skua: the influence of colony, diet and trophic status inferred from stable isotope signatures. Mar. Ecol. Prog. Ser. 195, 261-268.

Bearhop, S., Waldron, S., Thompson, D., Furness, R., 2000b. Bioamplification of mercury in great skua Catharacta skua chicks: the influence of trophic status as determined by stable isotope signatures of blood and feathers. Mar. Pollut. Bull. 40, 181-185.

Blévin, P., Carravieri, A., Jaeger, A., Chastel, O., Bustamante, P., Cherel, Y., 2013.Wide range of mercury contamination in chicks of southern ocean seabirds. PLoS One 8, e54508.

Bocher, P., Caurant, F., Miramand, P., Cherel, Y., Bustamante, P., 2003. Influence of the diet on the bioaccumulation of heavy metals in zooplankton-eating petrels at Kerguelen archipelago, Southern Indian Ocean. Polar Biol. 26, 759-767.

Borgå, K., Campbell, L., Gabrielsen, G.W., Norstrom, R.J., Muir, D.C.G., Fisk, A.T., 2006. Regional and species specific bioaccumulation of major and trace elements in Arctic seabirds. Environ. Toxicol. Chem. 25, 2927-2936.

Brasso, R.L., Polito, M.J., Lynch, H.J., Naveen, R., Emslie, S.D., 2012. Penguin eggshell membranes reflect homogeneity of mercury in the marine food web surrounding the Antarctic Peninsula. Sci. Total Environ. 439, 165-171.

Burchett, M.S., 1983. Food, feeding and behaviour of Notothenia rossii marmorata nearshore at South Georgia. Br. Antarct. Surv. Bull. 61, 45-51.

Burnham, K.P., Anderson, D.R., 2002. Model Selection and Multimodel Inference. 2nd ed. Springer.

Bustamante, P., Bocher, P., Cherel, Y., Miramand, P., Caurant, F., 2003. Distribution of trace elements in the tissues of benthic and pelagic fish from the Kerguelen Islands. Sci. Total Environ. 313, 25-39.

Bustamante, P., Carravieri, A., Goutte, A., Barbraud, C., Delord, K., Chastel, O., Weimerskirch, H., Cherel, Y., 2016. High feather mercury concentrations in the wandering albatross are related to sex, breeding status and trophic ecology with no demographic consequences. Environ. Res. 144, 1-10.

Campbell, L.M., Norstrom, R.J., Hobson, K. a, Muir, D.C.G., Backus, S., Fisk, A.T., 2005. Mercury and other trace elements in a pelagic Arctic marine food web (Northwater Polynya, Baffin Bay). Sci. Total Environ. 351-352, 247-263.

Carravieri, A., Bustamante, P., Churlaud, C., Cherel, Y., 2013. Penguins as bioindicators of mercury contamination in the Southern Ocean: birds from the Kerguelen Islands as 
a case study. Sci. Total Environ. 454-455, 141-148.

Carravieri, A., Bustamante, P., Tartu, S., Meillère, A., Labadie, P., Budzinski, H., Peluhet, L., Barbraud, C., Weimerskirch, H., Chastel, O., Cherel, Y., 2014a. Wandering albatrosses document latitudinal variations in the transfer of persistent organic pollutants and mercury to southern ocean predators. Environ. Sci. Technol. 48, 14746-14755.

Carravieri, A., Cherel, Y., Blévin, P., Brault-Favrou, M., Chastel, O., Bustamante, P., 2014b. Mercury exposure in a large subantarctic avian community. Environ. Pollut. 190C, 51-57.

Casaux, R., Soave, G., Coria, N., 1998. Lanternfish (Myctophidae) in the diet of the Cape petrel Daption capense at the South Shetland and South Orkney Islands, Antarctica. Polar Biol. 20, 364-366.

Casaux, R., Baroni, A., Ramón, A., Favero, M., Silva, P., 2008. Aspects of the foraging behaviour of the Antarctic Tern Sterna vittata gaini at Harmony Point, South Shetland Islands. Polar Biol. 31, 327-331.

Cherel, Y., Bocher, P., Trouvé, C., Weimerskirch, H., 2002. Diet and feeding ecology of blue petrels Halobaena caerulea at Iles Kerguelen, Southern Indian Ocean. Mar. Ecol. Prog. Ser. 228, 283-299.

Cherel, Y., Hobson, K.A., Bailleul, F., Groscolas, R., 2005. Nutrition, physiology, and stable isotopes: new information from fasting and molting penguins. Ecology 86, 2881-2888.

Cherel, Y., Phillips, R.A., Hobson, K.A., McGill, R., 2006. Stable isotope evidence of diverse species-specific and individual wintering strategies in seabirds. Biol. Lett. 2, 301-303.

Cherel, Y., Ducatez, S., Fontaine, C., Richard, P., Guinet, C., 2008. Stable isotopes reveal the trophic position and mesopelagic fish diet of female southern elephant seals breeding on the Kerguelen Islands. Mar. Ecol. Prog. Ser. 370, 239-247.

Chouvelon, T., Spitz, J., Caurant, F., Mèndez-Fernandez, P., Autier, J., Lassus-Débat, A., Chappuis, A., Bustamante, P., 2012a. Enhanced bioaccumulation of mercury in deep-sea fauna from the Bay of Biscay (north-east Atlantic) in relation to trophic positions identified by analysis of carbon and nitrogen stable isotopes. Deep-Sea Res. I Oceanogr. Res. Pap. $65,113-124$.

Chouvelon, T., Spitz, J., Caurant, F.,Mèndez-Fernandez, P., Chappuis, A., Laugier, F., Le Goff, E., Bustamante, P., 2012b. Revisiting the use of $\delta 15 \mathrm{~N}$ in meso-scale studies of marine food webs by considering spatio-temporal variations in stable isotopic signatures the case of an open ecosystem: The Bay of Biscay (North-East Atlantic). Prog. Oceanogr. 101, 92-105.

Choy, E.S., Gauthier, M., Mallory, M.L., Smol, J.P., Douglas, M.S.V., Lean, D., Blais, J.M., 2010. An isotopic investigation of mercury accumulation in terrestrial food webs adjacent to an Arctic seabird colony. Sci. Total Environ. 408, 1858-1867.

Cipro, C.V.Z., Taniguchi, S., Montone, R.C., 2010. Occurrence of organochlorine compounds in Euphausia superba and unhatched eggs of Pygoscelis genus penguins from Admiralty Bay (King George Island, Antarctica) and estimation of biomagnification factors. Chemosphere 78, 767-771.

Cipro, C.V.Z., Yogui, G.T., Bustamante, P., Taniguchi, S., Sericano, J.L., Montone, R.C., 2011. Organic pollutants and their correlation with stable isotopes in vegetation from King George Island, Antarctica. Chemosphere 85, 393-398.

Cipro, C.V.Z., Bustamante, P., Taniguchi, S., Montone, R.C., 2012. Persistent organic pollutants and stable isotopes in pinnipeds from King George Island, Antarctica. Mar. Pollut. Bull. 64, 2650-2655.

Cipro, C.V.Z., Colabuono, F.I., Taniguchi, S., Montone, R.C., 2013. Persistent organic pollutants in bird, fish and invertebrate samples from King George Island, Antarctica. Antarct. Sci. 25, 545-552.

Cipro, C.V.Z., Cherel, Y., Caurant, F., Miramand, P., Méndez-Fernandez, P., Bustamante, P., 2014. Trace elements in tissues of white-chinned petrels (Procellaria aequinoctialis) from Kerguelen waters, Southern Indian Ocean. Polar Biol. 37, 763-771. 
Connan, M., Mayzaud, P., Trouvé, C., Barbraud, C., Cherel, Y., 2008. Interannual dietary changes and demographic consequences in breeding blue petrels from Kerguelen Islands. Mar. Ecol. Prog. Ser. 373, 123-135.

Coquery, M., Azemard, S., Mora, S., 2001. The analytical performance study for the Medpol region: determination of trace elements and methylmercury in estuarine sediment sample. IAEA Report n 405 (64pp.).

Corbisier, T.N., Petti, M.A.V., Skowronski, R.S.P., Brito, T.A.S., 2004. Trophic relationships in the nearshore zone of Martel Inlet (King George Island, Antarctica): $\delta^{13} \mathrm{C}$ stable-isotope analysis. Polar Biol. 27, 75-82.

Coria, N., Soave, G., Montalti, D., 1997. Diet of Cape petrel Daption capense during the posthatching period at Laurie Island, South Orkney Islands, Antarctica. Polar Biol. 18, 236239.

Corsolini, S., 2009. Industrial contaminants in Antarctic biota. J. Chromatogr. A 1216, 598612.

DeNiro, M., Epstein, S., 1978. Influence of diet on the distribution of carbon isotopes in animals. Geochim. Cosmochim. Acta 42, 495-506.

dos Santos, I.R., Silva-Filho, E.V., Schaefer, C., Maria Sella, S., Silva, C.A., Gomes, V., Passos, M.J.D.A.C.R., Van Ngan, P., 2006. Baseline mercury and zinc concentrations in terrestrial and coastal organisms of Admiralty Bay, Antarctica. Environ. Pollut. 140, 304311.

Driscoll, C.T.,Mason, R.P., Chan, H.M., Jacob, D.J., Pirrone, N., 2013. Mercury as a Global Pollutant: Sources, Pathways, and Effects.

Dunton, K.H., 2001. $\delta^{15} \mathrm{~N}$ and $\delta^{13}$ Cmeasurements of Antarctic peninsula fauna: trophic relationships and assimilation of benthic seaweeds. Am. Zool. 41, 99-112.

Favero, M., Silva, P., Ferreyra, G., 1997. Trophic relationships between the kelp gull and the Antarctic limpet at King George Island (South Shetland Islands, Antarctica) during the breeding season. Polar Biol. 17, 431-436.

Fitzgerald,W., Engstrom, D., Mason, R., Nater, E., 1998. The case for atmospheric mercury contamination in remote areas. Environ. Sci. Technol. 32, 1-7.

Fitzgerald, W.F., Lamborg, C.H., Hammerschmidt, C.R., 2007. Marine biogeochemical cycling of mercury. Chem. Rev. 107, 641-662.

Forero, M., González-Solís, J., Hobson, K., Donázar, J., Bertellotti, M., Blanco, G., Bortolotti, G., 2005. Stable isotopes reveal trophic segregation by sex and age in the southern giant petrel in two different food webs. Mar. Ecol. Prog. Ser. 296, 107-113.

González-Solís, J., Sanpera, C., Ruiz, X., 2002.Metals and seleniumas bioindicators of geographic and trophic segregation in giant petrels. Mar. Ecol. Prog. Ser. 244, 257-264.

Goutte, A., Bustamante, P., Barbraud, C., 2014. Demographic responses to mercury exposure in two closely-related Antarctic top predators. Ecology 95, 1075-1086.

Goutte, A., Cherel, Y., Churlaud, C., Ponthus, J.-P., Massé, G., Bustamante, P., 2015. Trace elements in Antarctic fish species and the influence of foraging habitats and dietary habits on mercury levels. Sci. Total Environ. 538, 743-749.

Hobson, K.A., Clark, R.G., 1992. Assessing avian diets using stable isotopes I: turnover of ${ }^{13} \mathrm{C}$ in tissues. Condor 94, 181.

Hsu-Kim, H., Kucharzyk, K.H., Zhang, T., Deshusses, M.A., 2013. Mechanisms regulating mercury bioavailability for methylating microorganisms in the aquatic environment: a critical review. Environ. Sci. Technol. 47, 2441-2456.

Johnson, J.B., Omland, K.S., 2004. Model selection in ecology and evolution. Trends Ecol. Evol. 19, 101-108.

Lee, Y.I., Lim, H.S., Yoon, H.I., 2009. Carbon and nitrogen isotope composition of vegetation on King George Island, maritime Antarctic. Polar Biol. 32, 1607-1615.

Lesage, V., Hammill, M.O., Kovacs, K.M., 2002. Diet-tissue fractionation of stable carbon and nitrogen isotopes in phocid seals. Mar. Mammal Sci. 18, 182-193. 
Lewis, R., O’Connell, T.C., Lewis, M., Campagna, C., Hoelzel, a R., 2006. Sex-specific foraging strategies and resource partitioning in the southern elephant seal (Mirounga leonina). Proc. R. Soc. B Biol. Sci. 273, 2901-2907.

Locarnini, S., Presley, B., 1995. Trace element concentrations in Antarctic krill, Euphausia superba. Polar Biol. 15, 283-288.

Lukowski, A.B., 1978. DDT and its metabolites in Antarctic birds. Pol. Arch. Hydrobiol. 25 (3), 663-668.

Majer, A.P., Petti, M.A.V., Corbisier, T.N., Ribeiro, A.P., Theophilo, C.Y.S., Ferreira, P.A.D.L., Figueira, R.C.L., 2014. Bioaccumulation of potentially toxic trace elements in benthic organisms of Admiralty Bay (King George Island, Antarctica). Mar. Pollut. Bull. 79, 321-325.

Mão de Ferro, A., Mota, A.M., Canário, J., 2014. Pathways and speciation of mercury in the environmental compartments of Deception Island, Antarctica. Chemosphere 95, 227-233.

Miller, A.K., Karnovsky, N.J., Trivelpiece, W.Z., 2009. Flexible foraging strategies of Gentoo penguins Pygoscelis papua over 5 years in the South Shetland Islands, Antarctica. Mar. Biol. 156, 2527-2537.

Monteiro, L.R., Costa, V., Furness, R.W., Santos, R.S., 1996. Mercury concentrations in prey fish indicate enhanced bioaccumulation in mesopelagic environments. Mar. Ecol. Prog. Ser. 141, 21-25.

Morel, F.M.M., Kraepiel, A.M.L., Amyot, M., 1998. The chemical cycle and bioaccumulation of mercury. Annu. Rev. Ecol. Syst. 29, 543-566.

Moreno, J.D., Gerpe, M., Moreno, V., Vodopivez, C., 1997. Heavy metals in Antarctic organisms. Polar Biol. 17, 131-140.

Mougeot, F., Genevois, F., Bretagnolle, V., 1998. Predation on burrowing petrels by the brown skua (Catharacta skua lonnbergi) at Mayes Island, Kerguelen. J. Zool. Lond. 244, 429-438.

Park, H., Lee, S.-H., Kim, M., Kim, J.-H., Lim, H.S., 2009. Polychlorinated biphenyl congeners in soils and lichens from King George Island, South Shetland Islands, Antarctica. Antarct. Sci. 22, 31.

Peter, H.-U., Kaiser, M., Gebauer, A., 1990. Ecological and morphological investigations on South Polar Skuas (Catharacta maccormicki) and Brown Skuas (Catharacta skua lonnbergi) on Fildes Peninsula, King George Island, South Shetland Islands. Zool. Jahrb. Abt. Syst. Ökol. Geogr. Tiere 117, 201-218.

Polito, M.J., Lynch, H.J., Naveen, R., Emslie, S.D., 2011. Stable isotopes reveal regional heterogeneity in the pre-breeding distribution and diets of sympatrically breeding Pygoscelis spp. penguins. Mar. Ecol. Prog. Ser. 421, 265-277.

Reinhardt, K., Hahn, S., Peter, H., Wemhoff, H., 2000. A review of the diets of Southern Hemisphere skuas. Mar. Ornithol. 28, 7-19.

Roosens, L., Van Den Brink, N., Riddle, M., Blust, R., Neels, H., Covaci, A., 2007. Penguin colonies as secondary sources of contamination with persistent organic pollutants. J. Environ. Monit. 9, 822-825.

Schroeder, W.H., Anlauf, K.G., Barrie, L.A., Lu, J.Y., Steffen, A., Schneeberger, D.R., Berg, T., 1998. Arctic springtime depletion of mercury. Nature 394, 331-332.

Selin, N.E., 2009. Global biogeochemical cycling of mercury: a review. Annu. Rev. Environ. Resour. 34, 43-63.

Smichowski, P., Vodopivez, C., Muñoz-Olivas, R., María Gutierrez, A., 2006. Monitoring trace elements in selected organs of Antarctic penguin (Pygoscelis adeliae) by plasmabased techniques. Microchem. J. 82, 1-7.

Soerensen, A.L., Skov, H., Jacob, D.J., Soerensen, B.T., Johnson, M.S., 2010. Global concentrations of gaseous elemental mercury and reactive gaseous mercury in the marine boundary layer. Environ. Sci. Technol. 44, 7425-7430. 
Suda, C.N.K., Vani, G.S., de Oliveira, M.F., Rodrigues, E., Rodrigues, E., Lavrado, H.P., 2015. The biology and ecology of the Antarctic limpet Nacella concinna. Polar Biol. 38, 1949-1969.

Szefer, P., Czarnowski, W., Pempkowiak, J., Holm, E., 1993. Mercury and major essential elements in seals, penguins, and other representative fauna of the Antarctic. Arch. Environ. Contam. Toxicol. 25, 422-427.

Trivelpiece,W., Trivelpiece, S., Volkman, N., 1987. Ecological segregation of Adelie, gentoo, and chinstrap penguins at King George Island, Antarctica. Ecology 68, 351-361.

Yamamoto, Y., Honda, K., Tatsukawa, R., 1987. Heavy Metal Accumulation in Antarctic Krill Euphausia superba. Proceedings of the National Institute of Polar Research Symposium on Polar Biology 1, pp. 198-204. 
Table 1. SIA ( $\delta^{13} \mathrm{C}$ and $\delta^{15} \mathrm{~N}$, in\%o) and $\mathrm{Hg}$ (in $\mu \mathrm{g} \mathrm{g}{ }^{-1}$, dry weight), with its respective standard deviations $(\sigma)$.

\begin{tabular}{|c|c|c|c|c|c|c|c|c|}
\hline Species & Tissue & $\mathrm{n}$ & $\delta^{13} \mathrm{C}$ & $\sigma$ & $\delta^{15} \mathrm{~N}$ & $\sigma$ & $\mathrm{Hg}$ & $\sigma$ \\
\hline Euphausia superba & Whole & 4 & -25.66 & 0.69 & 4.51 & 0.53 & 0.018 & 0.005 \\
\hline Nacella concinna & Soft part & 8 & -16.10 & 1.74 & 7.27 & 1.23 & 0.037 & 0.015 \\
\hline Notothenia coriiceps & Muscle & 1 & -20.06 & - & 10.80 & - & 0.093 & - \\
\hline N. rossii & Muscle & 28 & -21.53 & 1.09 & 10.21 & 0.69 & 0.077 & 0.027 \\
\hline \multirow[t]{2}{*}{ Catharacta sp. } & Egg & 4 & -24.34 & 0.14 & 11.13 & 0.39 & 2.520 & 1.709 \\
\hline & Liver & 3 & -24.08 & 0.47 & 12.11 & 0.44 & 5.136 & 5.701 \\
\hline Daption capense & Liver & 2 & -25.76 & - & 10.45 & - & 6.965 & - \\
\hline \multirow[t]{2}{*}{ Larus dominicanus } & Egg & 3 & -23.36 & 2.29 & 9.13 & 0.68 & 0.195 & 0.067 \\
\hline & Liver & 3 & -23.42 & 2.69 & 11.64 & 3.74 & 11.02 & 16.82 \\
\hline Macronectes giganteus & Liver & 3 & -23.46 & 1.97 & 12.38 & 2.77 & 25.47 & 31.63 \\
\hline \multirow[t]{2}{*}{ Pygoscelis adeliae } & Egg & 3 & -25.27 & 1.06 & 9.66 & 0.53 & 0.075 & 0.049 \\
\hline & Liver & 5 & -26.11 & 1.31 & 8.67 & 0.96 & 1.742 & 3.527 \\
\hline \multirow[t]{2}{*}{ P. antarctica } & Egg & 26 & -25.52 & 0.55 & 9.99 & 0.29 & 0.599 & 0.273 \\
\hline & Liver & 16 & -25.38 & 1.87 & 8.93 & 1.46 & 1.906 & 1.265 \\
\hline \multirow[t]{2}{*}{ P. papua } & Egg & 9 & -25.96 & 0.53 & 9.27 & 0.24 & 0.133 & 0.037 \\
\hline & Liver & 16 & -25.88 & 0.57 & 8.99 & 0.68 & 0.369 & 0.275 \\
\hline Sterna vittata & Egg & 1 & -23.32 & - & 9.39 & - & 0.664 & - \\
\hline \multirow[t]{3}{*}{ Arctocephalus gazella } & Liver & 1 & -25.01 & - & 11.13 & - & 48.71 & - \\
\hline & Muscle & 2 & -24.19 & 0.43 & 9.09 & 1.07 & 0.091 & 0.049 \\
\hline & Skin & 3 & -21.62 & - & 10.66 & - & 0.028 & - \\
\hline \multirow[t]{4}{*}{ Leptonychotes weddellii } & Kidney & 1 & -25.55 & - & 8.02 & - & 0.075 & - \\
\hline & Liver & 1 & -24.31 & - & 12.54 & - & 0.286 & - \\
\hline & Muscle & 2 & -24.02 & 1.00 & 10.71 & 3.90 & 0.112 & 0.005 \\
\hline & Skin & 2 & -23.81 & - & 14.73 & - & 0.260 & - \\
\hline \multirow[t]{2}{*}{ Lobodon carcinophagus } & Muscle & 1 & -22.68 & - & 11.26 & - & 0.124 & - \\
\hline & Skin & 2 & -23.32 & - & 11.84 & - & 0.191 & - \\
\hline \multirow[t]{2}{*}{ Mirounga leonina } & Liver & 2 & -23.71 & - & 10.21 & - & 25.68 & - \\
\hline & Muscle & 1 & -23.09 & - & 10.22 & - & 0.613 & - \\
\hline Colobanthus quitensis & Whole & 1 & -25.31 & - & 12.79 & - & 0.014 & - \\
\hline Brachythecium sp. & Whole & 1 & -21.64 & - & -0.53 & - & 0.086 & - \\
\hline Sanionia uncinata & Whole & 7 & -24.32 & 0.49 & 6.40 & 7.32 & 0.068 & 0.026 \\
\hline Syntrichia princeps & Whole & 2 & -24.40 & 2.25 & 4.70 & 3.35 & 0.057 & 0.030 \\
\hline Unidentified moss & Whole & 1 & -24.10 & - & 11.77 & - & 0.100 & - \\
\hline Usnea antarctica & Whole & 3 & -21.13 & - & -6.20 & - & 0.152 & 0.032 \\
\hline U. aurantiaco-atra & Whole & 5 & -19.33 & 1.07 & -1.29 & 5.07 & 0.132 & 0.037 \\
\hline Usnea sp. & Whole & 1 & -20.74 & - & -7.67 & - & 0.210 & - \\
\hline Unidentified lichen & Whole & 2 & -21.01 & - & -1.01 & - & 0.227 & 0.115 \\
\hline
\end{tabular}


Table 2. Akaike information criterion for small sample sizes (AICc) on the two subsets of samples

\begin{tabular}{|c|c|c|c|c|c|c|}
\hline & & & & $\mathrm{AICc}$ & $\Delta$ AICC & $\mathrm{w}_{\mathrm{i}}$ \\
\hline \multicolumn{7}{|l|}{ Animals } \\
\hline$\delta^{15} \mathrm{~N}$ & Tissue & & & 20.93 & 0.00 & 0.59 \\
\hline$\delta^{13} \mathrm{C}$ & $\delta^{15} \mathrm{~N}$ & Tissue & & 22.84 & 1.91 & 0.23 \\
\hline$\delta^{15} \mathrm{~N}$ & Species & & & 25.27 & 4.33 & 0.07 \\
\hline$\delta^{15} \mathrm{~N}$ & Species & Tissue & & 25.35 & 4.41 & 0.06 \\
\hline$\delta^{13} \mathrm{C}$ & $\delta^{15} \mathrm{~N}$ & Species & & 27.07 & 6.14 & 0.03 \\
\hline$\delta^{13} \mathrm{C}$ & $\delta^{15} \mathrm{~N}$ & Species & Tissue & 27.18 & 6.25 & 0.03 \\
\hline \multicolumn{7}{|l|}{ Plants } \\
\hline$\delta^{13} \mathrm{C}$ & Species & & & -72.82 & 0.00 & 0.68 \\
\hline$\delta^{13} \mathrm{C}$ & $\delta^{15} \mathrm{~N}$ & Species & & -71.35 & 1.46 & 0.32 \\
\hline Species & & & & -53.26 & 19.56 & 0.00 \\
\hline$\delta^{15} \mathrm{~N}$ & Species & & & -51.19 & 21.62 & 0.00 \\
\hline$\delta^{13} \mathrm{C}$ & & & & -29.53 & 43.29 & 0.00 \\
\hline$\delta^{15} \mathrm{~N}$ & & & & -28.60 & 44.22 & 0.00 \\
\hline$\delta^{13} \mathrm{C}$ & $\delta^{15} \mathrm{~N}$ & & & -27.99 & 44.83 & 0.00 \\
\hline
\end{tabular}




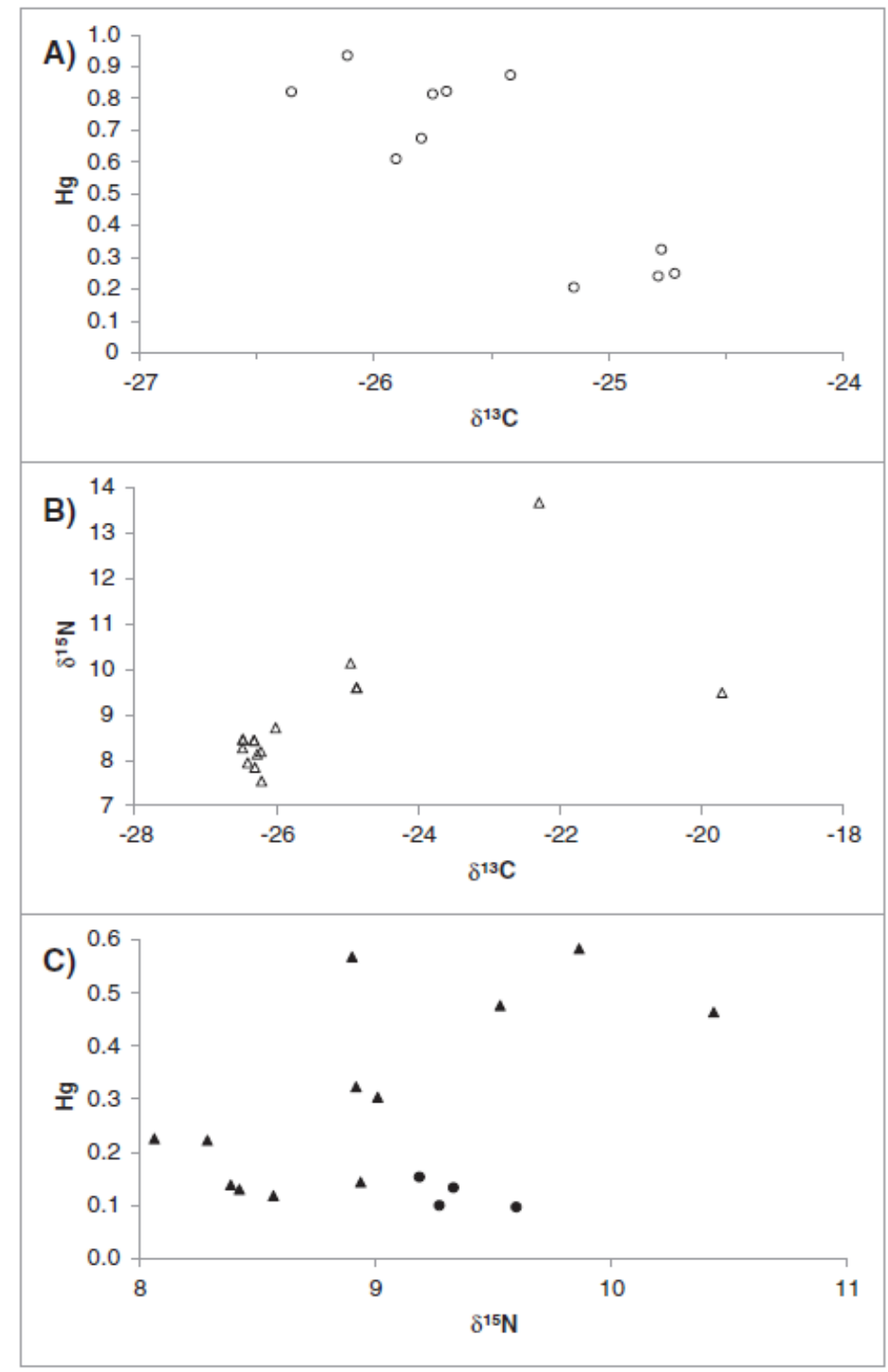

Figure 1. Significant correlations between $\mathrm{Hg}\left(\mu \mathrm{g} \mathrm{g} \mathrm{g}^{-1} \mathrm{dwt}\right)$ and stable isotopes (\%o) for A) Pygocelis antarctica eggs; B) P. antarctica liver and C) Pygocelis papua egg and liver. Empty markers for $P$. antarctica, filled ones for $P$. papua. Round markers for eggs, triangular ones for liver. 